\title{
Measuring the Impact of Selected Plants on Indoor $\mathrm{CO}_{2}$ Concentrations
}

\author{
Mehmet Cetin ${ }^{1 *}$, Hakan Sevik ${ }^{2}$ \\ ${ }^{1}$ Kastamonu University, Faculty of Engineering and Architecture, Department of Landscape Architecture, \\ 37150, Kastamonu, Turkey \\ ${ }^{2}$ Kastamonu University, Faculty of Engineering and Architecture, Department of Environmental Engineering, \\ 37150, Kastamonu, Turkey
}

Received: 25 September 2015

Accepted: 15 December 2015

\begin{abstract}
Nearly $90 \%$ of people's lives are lived indoors, and their health is affected by the concentrations of $\mathrm{CO}_{2}$ in these spaces. Carbon dioxide concentrations can rapidly change based on human activity in indoor living spaces. Indoor plants and the concentration of $\mathrm{CO}_{2}$ in the local environment are factors that influence most people. Plants, depending on the ambient light and temperature conditions, and which are necessary to perform photosynthesis or respiration, directly affect the concentration of $\mathrm{CO}_{2}$ in the local environment. Furthermore, indoor plants influence the level of $\mathrm{CO}_{2}$ in the local environment but have not been researched enough in recent years concerning their specific effects. This study attempts to determine the effects of indoor plants on the concentration of $\mathrm{CO}_{2}$ in an indoor environment under certain light conditions. Five indoor plants were placed in a glass-walled compartment in order to measure the amount of $\mathrm{CO}_{2}$. The glass compartment used in the study was positioned in a way to prevent direct sunlight yet provide an illuminated environment. The plants were placed into this airtight compartment with a glass wall, which had a volume of approximately $0.5 \mathrm{~m}^{3}(0.7 \mathrm{mx} 0.7 \mathrm{mx} 1 \mathrm{~m})$. The measurements of $\mathrm{CO}_{2}$ within the compartment were carried out via Extech Desktop Indoor Air Quality $\mathrm{CO}_{2}$ Datalogger, and the $\mathrm{CO}_{2}$ measuring device placed in the compartment was set to measure $\mathrm{CO}_{2}$ once every five minutes. The study found that all plants reduced the concentration of $\mathrm{CO}_{2}$ to a certain extent during the day.
\end{abstract}

Keywords: air quality, people's health, carbon dioxide, $\mathrm{CO}_{2}$, indoor, indoor plants

\section{Introduction}

In $2000,47 \%$ of the world's population (2.9 billion people) lived in urban areas. Scientists have predicted that anywhere from $60 \%$ to $90 \%$ of the world's population will live in cities by the 2030s. In European countries, more than two thirds of the total population live in urban areas

*e-mail: mehmet.cetin@temple.edu
[1-3]. Also, people living in cities spend at least $80 \%$ of their lives in indoor spaces [4].

The quality of air in indoor spaces, then, is of great relevance to human health. Any decrease in indoor air quality directly affects human health and performance [5].

$\mathrm{CO}_{2}$ is one of the gases whose concentration can change rapidly as a result of indoor human metabolic activities. Air composed of $21 \% \mathrm{O}_{2}$ and $0.033 \% \mathrm{CO}_{2}$ taken in by people from the normal atmosphere becomes $16-17 \% \mathrm{O}_{2}$ and $4 \% \mathrm{CO}_{2}$ content during discharge from the 
lungs. This change leads to a rapid rise in $\mathrm{CO}_{2}$ content in environments like schools, shopping malls, and hospitals, where people tend to congregate [6]. Increases in the $\mathrm{CO}_{2}$ content in an environment can cause fatigue, absence of perception, and sleepiness. Furthermore, higher $\mathrm{CO}_{2}$ concentrations tend to bring about several complaints that result in loss of performance but whose cause cannot be easily determined. When the concentration of $\mathrm{CO}_{2}$ in an environment is more than 1,000 ppm, people experience headache, dizziness, fatigue, and loss of concentration, and they will notice and become annoyed by the odor of the gas; when the concentration of $\mathrm{CO}_{2}$ is more than 1,500 ppm, people experience throat irritation, nose irritation, nasal discharge, cough, and eye discharge [7].

One of the most effective ways to improve indoor air quality is maintaining proper ventilation. U.S. Environmental Protection Agency (EPA) studies show that the levels of pollutants in indoor environments can be between 5 and 100 times greater than outside air. The concentration of $\mathrm{CO}_{2}$ in external environments may vary according to many factors, including the presence or absence of woodlands, construction, traffic, the season, etc., but in any case indoor air should be ventilated to decrease the concentration of $\mathrm{CO}_{2}$.

One of the factors that influences indoor $\mathrm{CO}_{2}$ concentrations is the number of indoor plants. Indoor plants consume carbon dioxide and produce oxygen through photosynthesis [4]. Photosynthesis, however, depends on various environmental factors, such as light and temperature. When the necessary conditions are not met, plants begin respiration, taking $\mathrm{O}_{2}$ from the environment and replacing it with $\mathrm{CO}_{2}$.

While plants are the most important component to the oxygen and carbon cycle in nature, they are also important indoors. Plants have both a psychological and physical impact on people since they function both to improve the aesthetics of a space and to improve air quality. The concentration of $\mathrm{CO}_{2}$ in the indoor atmosphere, however, and the amount that plants change this concentration, is not well known.

In 2013, Kastamonu University carried out a research project titled "Plants of Indoor Air Quality in the Classroom Assisted Increasing Opportunities," in order to determine the effect of plants on $\mathrm{CO}_{2}$ concentrations in domestic environments. The project found that $\mathrm{CO}_{2}$ concentrations could change quickly depending on many factors, but this study did not clearly determine the influence of plants on the concentration of $\mathrm{CO}_{2}$ in domestic environments. Working in isolated environments to get more accurate information is necessary.

The effect of plants on indoor air quality has to be determined based on ambient conditions. Among these conditions, the most important are light and temperature. Temperature control is necessary for human comfort, and indoor spaces are usually kept between $20^{\circ} \mathrm{C}$ and $25^{\circ} \mathrm{C}$. This range is also ideal for the growth of plants.

Light levels, however, vary greatly in indoor environments. Unless an environment is artificially illuminated, the quantity of light in that environment changes depending on time of day. Such changes affect plant metabolic activities and thereby influence a plant's effect on indoor $\mathrm{CO}_{2}$ concentrations.

Plants can be used effectively to regulate the amount of carbon dioxide in an indoor environment. The number of studies on this issue, however, is rather limited. This study aims to determine the effects of select indoor plants on the concentration of $\mathrm{CO}_{2}$ in an indoor environment. Specifically, this study attempts to determine the effects of these plants based on the presence of sunlight.

\section{Materials and Methods}

Five species of common indoor plants were used for this study: Ficus elastica, Yucca massengena, Ocimum basilicum, Sinningia speciosa, and Codiaeum variegatum. Of these plants, Ficus elastica and Yucca massengena can reach considerable sizes in indoor spaces. Ocimum basilicum and Sinningia speciosa are often grown in indoor spaces for their scent and showy flowers, respectively.

The glass-walled compartment used in the study was positioned in a way that prevented direct sunlight but that provided an illuminated environment. Most indoor plants prefer illuminated environments that are not exposed to direct sunlight, and many indoor plants are grown in spaces that have these characteristics. The plants used in this study were placed in an airtight compartment with a glass wall that had a volume of approximately $0.5 \mathrm{~m}^{3}$ $(0.7 \mathrm{~m} \times 0.7 \mathrm{~m} \times 1 \mathrm{~m})$. The measurements of $\mathrm{CO}_{2}$ within the compartment were carried out via Extech Desktop Indoor Air Quality $\mathrm{CO}_{2}$ Datalogger, and the $\mathrm{CO}_{2}$ measuring device placed in the compartment was set to measure $\mathrm{CO}_{2}$ once every five minutes. The plants used in the study were placed in the compartment between 13:00 and 14:00, and the $\mathrm{CO}_{2}$ amount inside the space was raised.

During the time of this study, local sunrise was at around 05:05 and sunset at around 20:30. The measurements obtained at around 05:30 were included in the evaluation, and 28-hour measurement results were used in order to better determine the change in $\mathrm{CO}_{2}$ in one day. Accordingly, the plants were kept in the glass compartment for nearly 45 hours, but only the data obtained during the 28-hour period were used in the evaluation.

Before the study, the plants were watered routinely once per week, and the experiment was held one day after irrigation. In addition to routine maintenance, plants were given a liquid manure fertilizer (specifically for indoor plants) every two weeks in two separate waterings. All plants were set in peat soil.

\section{Results}

\section{The Effect of Ficus elastica on $\mathrm{CO}_{2}$ Concentrations}

The change in $\mathrm{CO}_{2}$ concentrations caused by Ficus elastica over time is given in Fig. 1. As seen in 


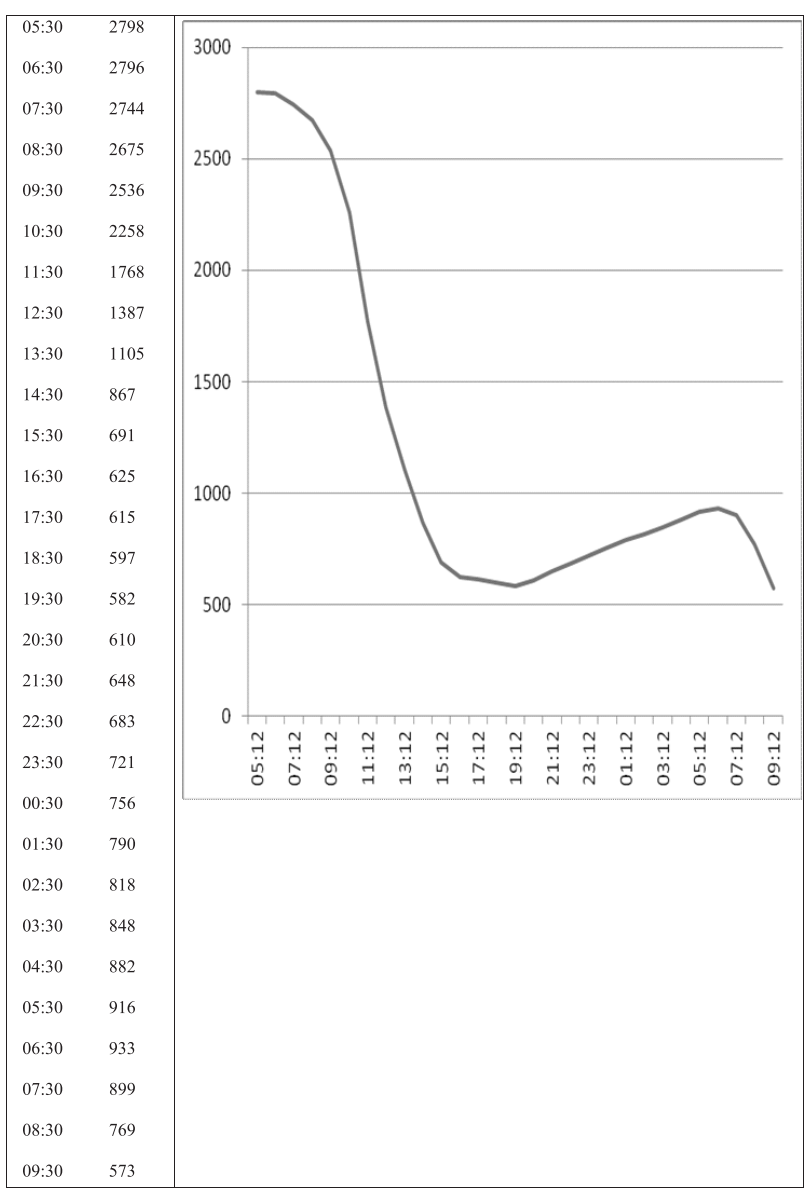

Fig. 1. Change in $\mathrm{CO}_{2}$ amount created by Ficus elastica in the course of time.

Fig. 1, Ficus elastica had a measurable effect on the $\mathrm{CO}_{2}$ concentrations in the test area. The $\mathrm{CO}_{2}$ concentration did not change significantly until around sunset, at which time $\mathrm{CO}_{2}$ increased until sunrise. The $\mathrm{CO}_{2}$ concentration, which started at $2,798 \mathrm{ppm}$ at $05: 30$, fell to $2,796 \mathrm{ppm}$ by 06:30. The $\mathrm{CO}_{2}$ concentration then decreased rapidly to $625 \mathrm{ppm}$ by $16: 30$ and $582 \mathrm{ppm}$ by 19:30. At this point, the concentration of $\mathrm{CO}_{2}$ began to increase, rising to 933 ppm by 6:30 on the following day. The $\mathrm{CO}_{2}$ concentration fell again after this point. In a 24-hour period, the $\mathrm{CO}_{2}$ concentration in the air decreased from $2,798 \mathrm{ppm}$ to $933 \mathrm{ppm}$. The $\mathrm{CO}_{2}$ concentration fell 2,216 ppm during the day and rose $351 \mathrm{ppm}$ during the night. Therefore, it can be said that during the day, Ficus elastica consumes approximately 6.3 times as much $\mathrm{CO}_{2}$ as it produces at night.

\section{The Effect of Yucca massengena on $\mathrm{CO}_{2}$ Concentrations}

The change in the $\mathrm{CO}_{2}$ concentration caused by Yucca massengena over time is given in Fig. 2. In the case of Yucca massengena, the $\mathrm{CO}_{2}$ concentration in the air was $3,310 \mathrm{ppm}$ at the beginning of the study period, and the concentration fell rapidly until reaching $855 \mathrm{ppm}$ at around 16:30. The pace of this decline in $\mathrm{CO}_{2}$ decreased

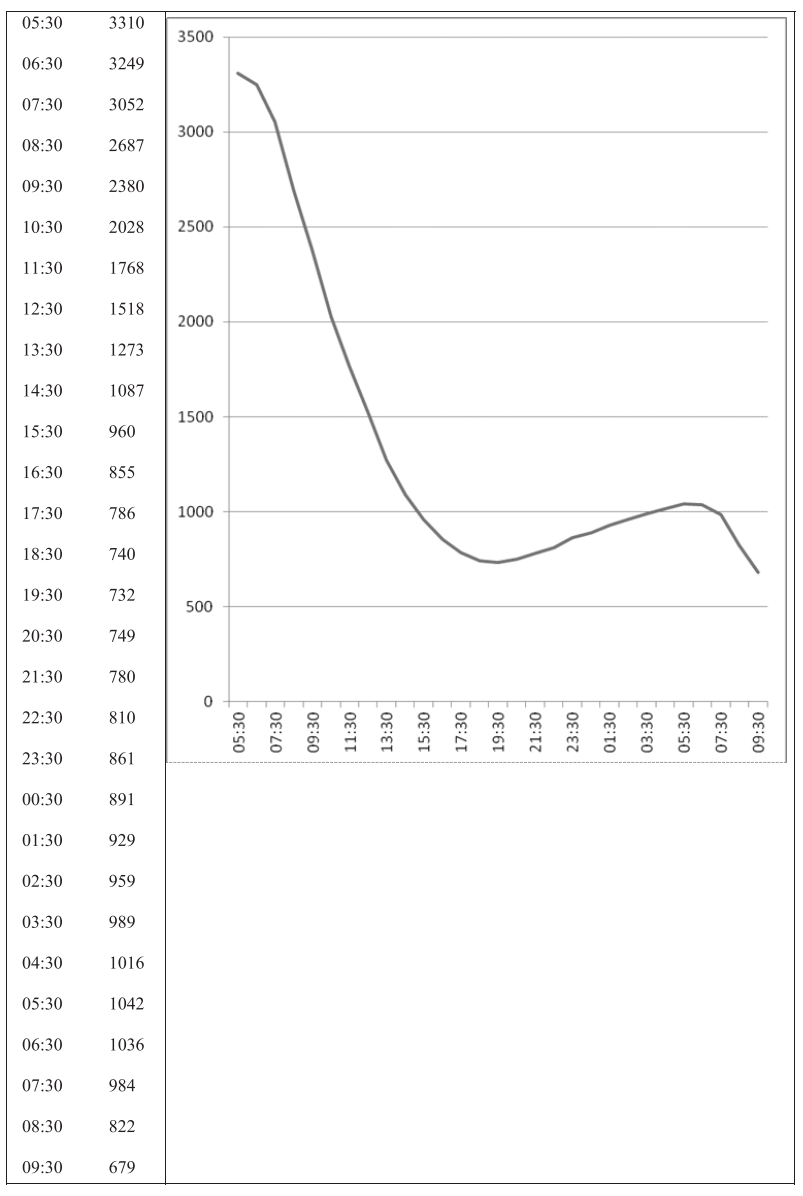

Fig. 2. Change in $\mathrm{CO}_{2}$ amount created by Yucca massengena in the course of time.

at this point, reducing the $\mathrm{CO}_{2}$ concentration further to $732 \mathrm{ppm}$, which was its lowest level, at 19:30. The $\mathrm{CO}_{2}$ concentration began to increase at 19:30. This increase continued until 05:30, at which time the $\mathrm{CO}_{2}$ concentration was $1,042 \mathrm{ppm}$. The $\mathrm{CO}_{2}$ concentration, which was 3,310 ppm at 05:30, decreased to $732 \mathrm{ppm}$ at 19:30. Thus a decrease of 2,578 ppm took place during the daytime. The $\mathrm{CO}_{2}$ concentration started to increase again at 19:30 and became 1,042 ppm by 05:30 the next morning. In other words, a rise of $310 \mathrm{ppm}$ occurred during the night. The $\mathrm{CO}_{2}$ concentration decreased a total of $2,268 \mathrm{ppm}$ in 24 hours. The decrease in the $\mathrm{CO}_{2}$ concentration during the day was approximately 8.3 times greater than the increase during the night.

\section{The Effect of Ocimum basilicum on $\mathrm{CO}_{2}$ Concentrations}

The change in the $\mathrm{CO}_{2}$ concentration caused by Ocimum basilicum over time is given in Fig. 3. The $\mathrm{CO}_{2}$ concentration started at $1,565 \mathrm{ppm}$ and decreased little until 09:30. The $\mathrm{CO}_{2}$ concentration then underwent a rapid fall, however, decreasing to $1,198 \mathrm{ppm}$ at 12:30. This rapid decrease ended at 12:30, after which time the $\mathrm{CO}_{2}$ concentration decreased to $1,148 \mathrm{ppm}$ by $16: 30$. After this point, the $\mathrm{CO}_{2}$ concentration followed a 


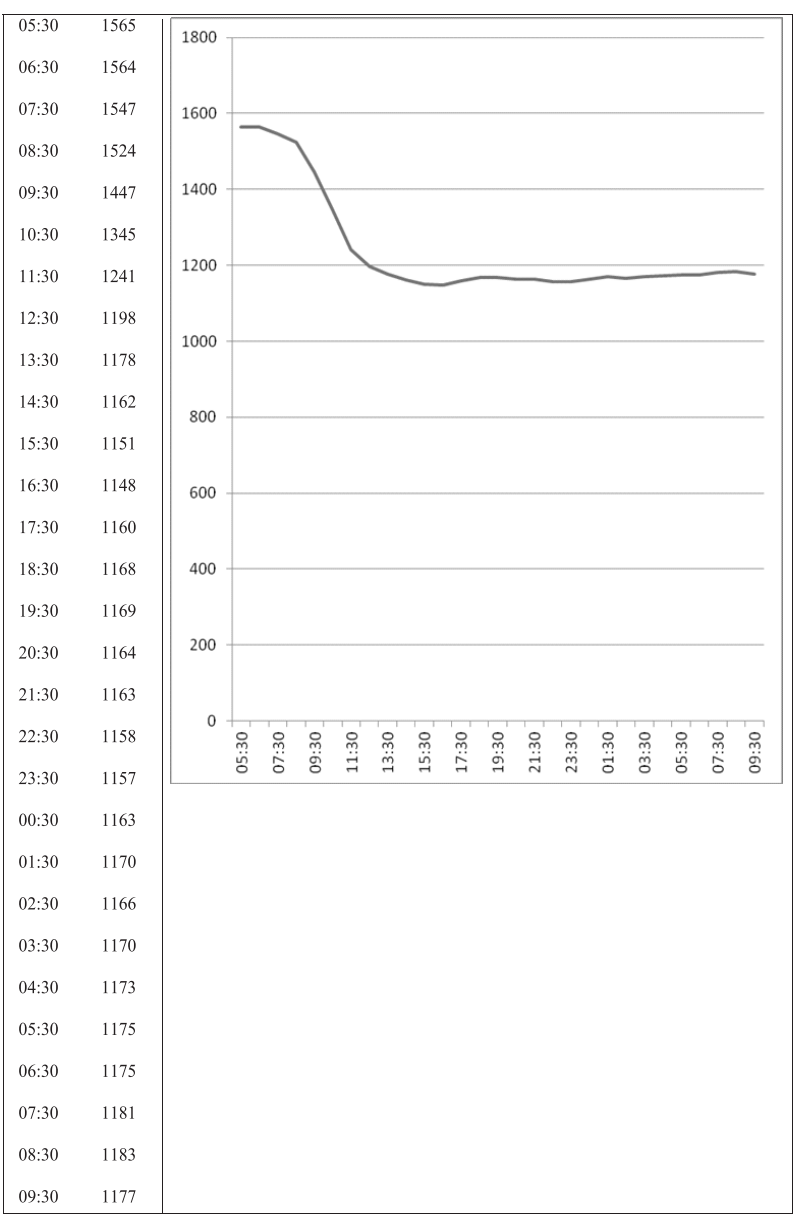

Fig. 3. Change in $\mathrm{CO}_{2}$ amount created by Ocimum basilicum in the course of time.

horizontal course. With little increase in total, it went up to $1,175 \mathrm{ppm}$ by $05: 30$ and to $1,183 \mathrm{ppm}$ by $08: 30$. These results indicate that the $\mathrm{CO}_{2}$ concentration went through a rapid decrease between 09:30 and 12:30 but followed an almost horizontal course at other times during the day, though it did continue to decrease slightly. The $\mathrm{CO}_{2}$ concentration, which was $1,164 \mathrm{ppm}$ at 20:30 at night, increased to $1,175 \mathrm{ppm}$ by $05: 30$ the next morning. Thus it increased only $11 \mathrm{ppm}$ in total. The $\mathrm{CO}_{2}$ concentration decreased $401 \mathrm{ppm}$ between 05:30 and 20:30 during the daytime. Of the $401 \mathrm{ppm}$ decrease, the concentration of $\mathrm{CO}_{2}$ decreased $206 \mathrm{ppm}$ between 09:30 and 11:30. This period represents the time that the environment containing Ocimum basilicum was the hottest and most illuminated.

\section{The Effect of Sinningia speciosa on $\mathrm{CO}_{2}$ Concentrations}

The change in $\mathrm{CO}_{2}$ concentration caused by Sinningia speciosa over time is given in Fig. 4. As shown in Fig. 4, the $\mathrm{CO}_{2}$ concentration was $2,583 \mathrm{ppm}$ at 05:30 in the environment containing Sinningia speciosa, and this concentration decreased until 17:30, at which point it was at $1,858 \mathrm{ppm}$. The $\mathrm{CO}_{2}$ concentration started to increase after this point and reached 2,091 ppm at 06:30.

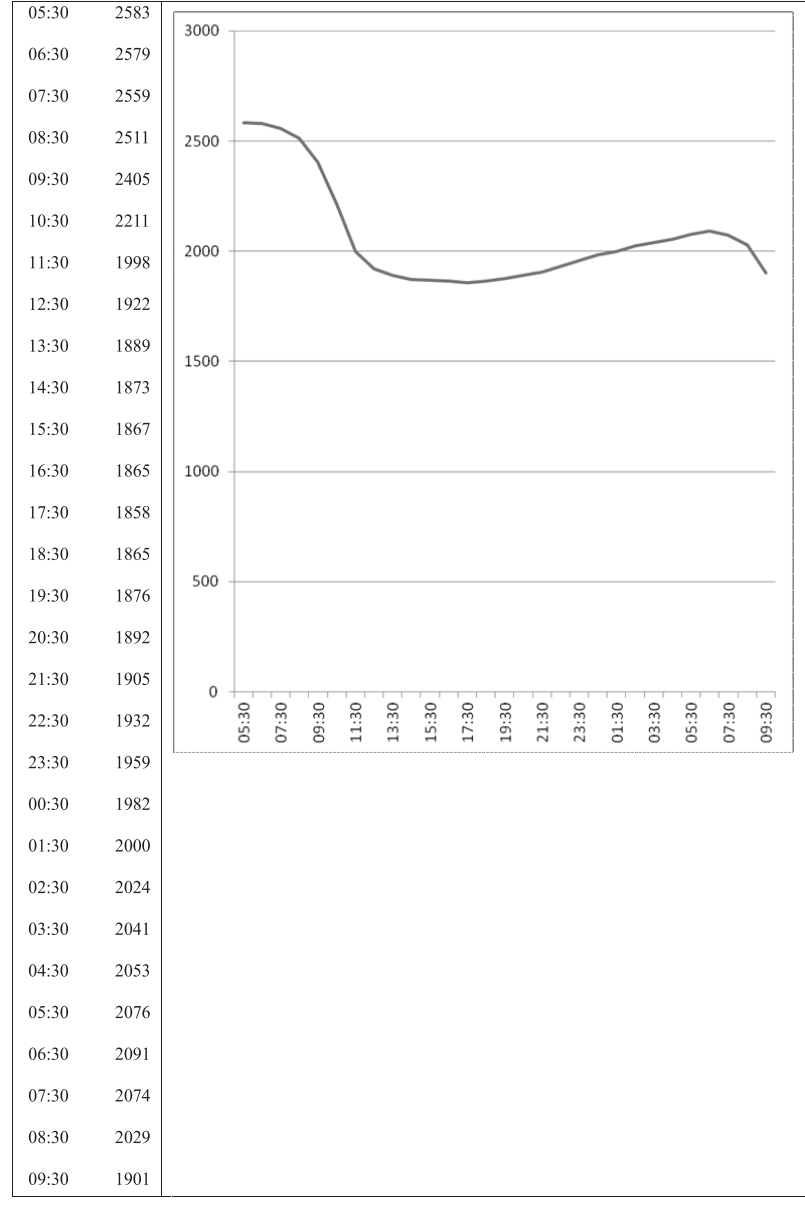

Fig. 4. Change in $\mathrm{CO}_{2}$ amount created by Sinningia speciosa in the course of time.

These figures clearly show that when the amount of light decreases in the environment containing Sinningia speciosa, photosynthesis stops and respiration starts. The $\mathrm{CO}_{2}$ concentration fell $725 \mathrm{ppm}$ in total during the day, decreasing from $2,583 \mathrm{ppm}$ to $1,858 \mathrm{ppm}$. However, the concentration increased to $2,076 \mathrm{ppm}$ from 17:30 to $05: 30$, a rise of $218 \mathrm{ppm}$. The decrease in the concentration of $\mathrm{CO}_{2}$ during the day was only 3.3 times greater than the increase at night. The total reduction in the $\mathrm{CO}_{2}$ concentration over the 24-hour period was $507 \mathrm{ppm}$.

\section{The Effect of Codiaeum variegatum on $\mathrm{CO}_{2}$ Concentrations}

The change in the $\mathrm{CO}_{2}$ concentration caused by Codiaeum variegatum over time is given in Fig. 5. In the case of Codiaeum variegatum, the $\mathrm{CO}_{2}$ concentration began at $1,861 \mathrm{ppm}$ at $05: 30$ and decreased to 1,071 by 19:30. The concentration of $\mathrm{CO}_{2}$ then increased to $1,155 \mathrm{ppm}$ by $05: 30$ the next morning. In other words, the $\mathrm{CO}_{2}$ concentration fell $790 \mathrm{ppm}$ during the day and increased $84 \mathrm{ppm}$ during the night. The amount of $\mathrm{CO}_{2}$ consumed during the day was approximately 9.4 times greater than the amount of $\mathrm{CO}_{2}$ given off at night. 


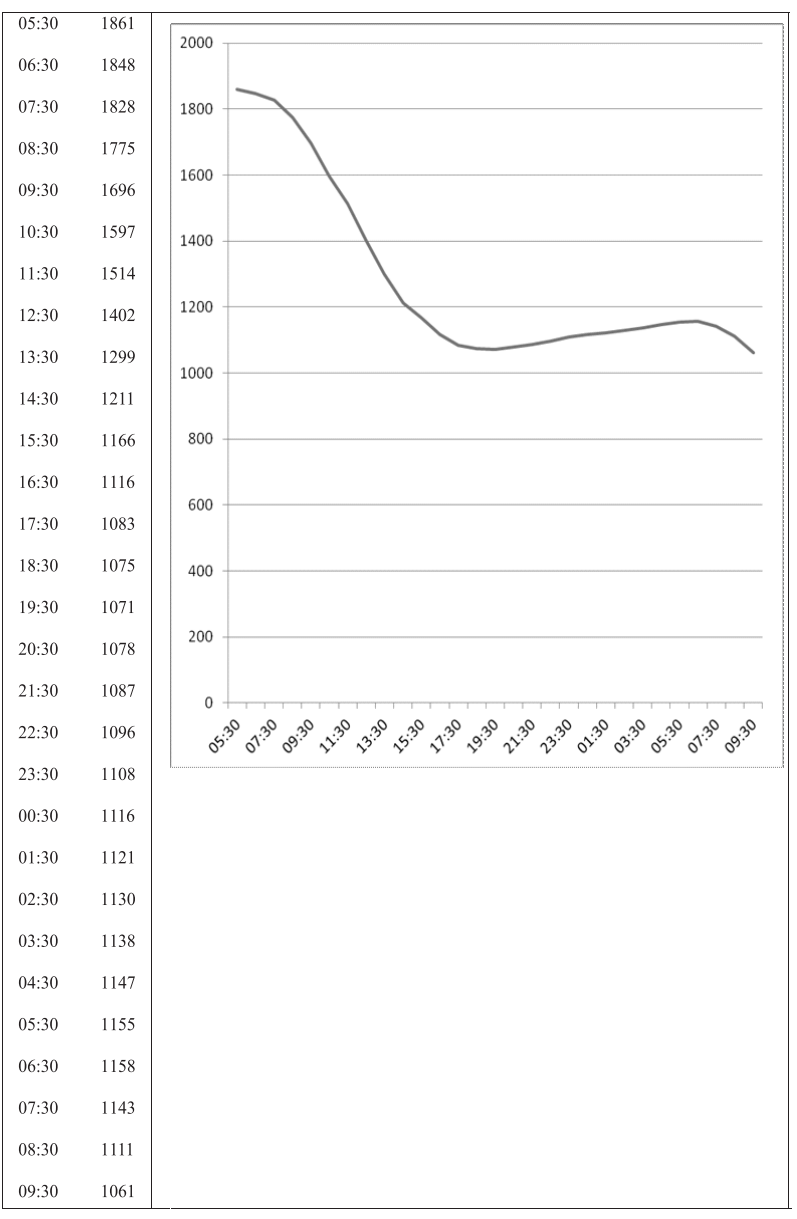

Fig. 5. Change in $\mathrm{CO}_{2}$ amount created by Codiaeum variegatum in the course of time.

\section{Discussion}

This study found that all of the selected plants reduced the $\mathrm{CO}_{2}$ concentration to a certain extent during the day. The $\mathrm{CO}_{2}$ concentration decreased 2,216 ppm in the case of Ficus elastica, 2,578 ppm in the case of Yucca massengena, $401 \mathrm{ppm}$ in the case of Ocimum basilicum, $725 \mathrm{ppm}$ in the case of Sinningia speciosa, and $790 \mathrm{ppm}$ in the case of Codiaeum variegatum. Ficus elastica and Yucca massengena both considerably reduced the concentration of $\mathrm{CO}_{2}$ in the air. Sinningia speciosa and Ocimum basilicum, on the other hand, had less of an effect on the $\mathrm{CO}_{2}$ concentration in the environment. These results were not surprising. While Ficus elastica and Yucca massengena are large indoor plants, Sinningia speciosa and Ocimum basilicum are smaller plants grown for their scent and flowers. The effect on the $\mathrm{CO}_{2}$ concentration was directly proportional to size. Although Codiaeum variegatum is a large plant, it had a limited effect on the $\mathrm{CO}_{2}$ concentration. That may be due to the anatomic structure of the plant. According to Kacar et al., [8] some plant leaves are thick and make less use of light. That may be true for Codiaeum variegatum, but the Ficus elastica used in this study had a significant effect on the $\mathrm{CO}_{2}$ concentration in the environment despite having a thick leaf structure. Therefore, the effectiveness of the plant at reducing $\mathrm{CO}_{2}$ concentrations may be due to the chlorophyll content in the leaves. The colors of the leaves of these two plants are noticeably different: the Ficus elastica has dark green leaves, but the Codiaeum variegatum has leaves containing various tones besides green, including yellow, red, and orange. The coloration of plants is determined by pigments that are categorized as chlorophylls, carotenoids, phycobilins, flavonoids, betalains, and betacyanins [9]. Among these pigments, chlorophyll provides plants with green color and enables photosynthesis [5]. Accordingly, the color of a plant's leaves indicates the quantity of chlorophyll, and the quantity of chlorophyll is one of the most important factors influencing photosynthesis.

Another remarkable finding of the study is that Codiaeum variegatum, Ficus elastica, and Yucca massengena reduced the concentration of $\mathrm{CO}_{2}$ even when the light level was low. Sinningia speciosa and Ocimum basilicum, on the other hand, either did not change the quantity of $\mathrm{CO}_{2}$ in the environment or actually increased it. This result may be due to the anatomic structures of the plants used in the study. According to Kacar et al., [8] the amount of light needed for photosynthesis may vary by plant species. They report, for example, that photosynthesis in Asarum caudatum reaches its peak when the quantity of light is $200 \mu \mathrm{mol} \mathrm{m} \mathrm{m}^{-2} \mathrm{~s}^{-1}$, while photosynthesis in Atriplex triangularis reaches its peak when the quantity of light is $1,700 \mu \mathrm{mol} \mathrm{m} \mathrm{s}^{-2}$.

The amount of $\mathrm{CO}_{2}$ consumed by the plants during the day was determined to be much more than the amount of $\mathrm{CO}_{2}$ produced by them at night. Since Ocimum basilicum had a limited effect on the increase in the $\mathrm{CO}_{2}$ concentration during the night, it was excluded from the calculation. The concentration of $\mathrm{CO}_{2}$ consumed by the plants (other than Ocimum basilicum) during the day ranged from 3.3 to 9.4 times the amount of $\mathrm{CO}_{2}$ produced by them at night.

As living organisms, plants require various conditions in order to survive. Additionally, they change ambient conditions through their metabolic activities. When ambient conditions are suitable for plant growth, they emit oxygen into the environment and absorb carbon dioxide from the environment, but the opposite is true when conditions change $[8,10]$. One study on this subject concluded that the concentration of $\mathrm{CO}_{2}$ in forestland is on average $391 \mathrm{ppm}$ during the day and $422 \mathrm{ppm}$ during the night in winter months, but it is on average $148 \mathrm{ppm}$ during the day and 229 ppm during the night in summer months [10].

Though plants are used for aesthetic purposes in landscaping, the fact that they affect the concentration of $\mathrm{CO}_{2}$ in the environment is well known [11]. Previous research reports that a beech tree that has a leaf surface of $1,600 \mathrm{~m}^{2}$ can meet the oxygen needs of 10 people [4]. According to Tarran et al., [12] the existence of plants reduces the concentration of $\mathrm{CO}_{2}$ by $10 \%$ in offices with an air-conditioner and by $25 \%$ in those with natural ventilation.

Studies on indoor plants have determined that the effect on the concentration of $\mathrm{CO}_{2}$ in the environment is 
significant. When considering plants of equal size in $1 \mathrm{~m}^{3}$ of air at $25^{\circ} \mathrm{C}$, Dieffenbachia amoena decreased the $\mathrm{CO}_{2}$ concentration by $480 \mathrm{ppm}$ in one hour, while Spathiphyllum floribundum decreased the $\mathrm{CO}_{2}$ concentration by 393 ppm, Ficus benjamina decreased the $\mathrm{CO}_{2}$ concentration by 315 ppm, and Yucca elephantipes reduced the concentration by around $93 \mathrm{ppm}$ [13]. In another study that identified how much the concentration of $\mathrm{CO}_{2}$ was reduced during the day among plants in equal atmospheric conditions, Schefflera arboricola reduced the concentration of $\mathrm{CO}_{2}$ by 1,252 ppm, Fuchsia magellanica reduced the concentration of $\mathrm{CO}_{2}$ by 252 ppm, and Ficus benjamina reduced the concentration of $\mathrm{CO}_{2}$ by $657 \mathrm{ppm}$ [14].

Research should be carried out with different plants with the aim of discovering plants that photosynthesize faster in indoor environmental conditions. Another issue to be researched is how to increase the photosynthesis rates of plants by changing indoor conditions. Intensity of light and type of light, for instance, should be the subject of research because the effect of plants on indoor air quality depends on photosynthesis. Previous research has shown that green plants photosynthesizing in adequate light conditions not only reduce the concentration of $\mathrm{CO}_{2}$ in the environment $[12,15]$, but they also decrease sulfur content [16] and improve air quality by filtering pollutants that are harmful to living beings (e.g., dust, ash, pollen, smoke, and particulate matter) $[17,18]$. Moreover, some studies have been conducted on the effects of plants in this regard $[12,13,19]$. Research in this field, however, should be increased and provide details that enable the practical use of plants to reduce $\mathrm{CO}_{2}$ concentrations in indoor spaces.

\section{Conclusions}

The findings of the present study offer important clues for choosing plants based on the characteristics of the environment and the time spent in the environment. For example, Ficus elastica and Yucca massengena considerably reduce the concentration of $\mathrm{CO}_{2}$ during the day, but substantially increase it during the night, relative to other plants. The use of these plants in places that are primarily occupied during the day, such as offices, classrooms, and shopping malls, may be beneficial. Codiaeum variegatum and Ocimum basilicum, however, which produce less $\mathrm{CO}_{2}$ at night, should be preferred in environments that are mostly used at night, such as houses, dormitories, and hotels. Likewise, the light received by the environment in which the plant is kept affects its ability to reduce the concentration of $\mathrm{CO}_{2}$. While Sinningia speciosa and Ocimum basilicum either do not change or just increase the concentrations of $\mathrm{CO}_{2}$ in the environments where the intensity of light is low, Ficus elastica, Codiaeum variegatum, and Yucca massengena reduce the concentrations of $\mathrm{CO}_{2}$ in their environments even when the intensity of light is low. Therefore, these plants will be better used in environments where the intensity of light is inadequate for other plants. As stated before, however, research on this subject is not sufficient, and such research should be increased and offer more details so that plants can be effectively used to reduce the concentrations of $\mathrm{CO}_{2}$ in indoor spaces.

\section{References}

1. CETIN M. Evaluation of the sustainable tourism potential of a protected area for landscape planning: a case study of the ancient city of Pompeipolis in Kastamonu. Int. J. Sust. Dev. World. 22 (6), 490, doi: 10.1080/13504509.2015.1081651, 2015.

2. KONIJNENDIJK C.C. A decade of urban forestry in Europe. Forestry Policy and Economics. 5 (2), 173, 2003.

3. SEVIK H., KARAKAS H., SENOZ E. Evaluation of air quality in terms of the amount of carbon dioxide in black sea region. International Journal of Engineering Science \& Research Technology. 2 (2), 805, 2013.

4. CETIN M. Determining the bioclimatic comfort in Kastamonu city. Environ. Monit. Assess. 187 (10), 640, 2015.

5. SEVIK H., KARAKAS H., KARACAU. Color - Chlorophyll relationship of some indoor ornamental plant, International Journal of Engineering Science \& Research Technology, 2 (7), 1706, 2013.

6. BULGURCU H., ILTEN N., COSGUN A. Indoor air quality problems and solutions in schools. Journal of Installation Engineering. 96, 59, 2006 [In Turkish].

7. ERCAN M.S. Your compass green "Environmental Indicator". X. International HVAC Technology Symposium, 169, 30 April-May, 2012, Istanbul, Turkey, 2012 [In Turkish].

8. KACAR B., KATKAT V., OZTURK S. Light, plant physiology. The Nobel Broadcast Distribution, Ankara, 270, 2010 [In Turkish].

9. KARAKURT H., ASLANTAS R. Plant material of color (pigment) formation and changes in physiology, Alatarım. 7 (2), 34, 2008 [In Turkish].

10. SEVIK H., CETIN M., BELKAYALI N. Effects of forests on amounts of $\mathrm{CO}_{2}$ : case study of Kastamonu and Ilgaz Mountain National Parks. Pol. J. Environ. Stud. 24 (1), 253, 2015.

11. CETIN M. Using GIS analysis to assess urban green space in terms of accessibility: case study in Kutahya. Int. J. Sust. Dev. World. 22 (5), 420, 2015.

12. TARRAN J., TORPY F., BURCHETT M. Use of Living PotPlants to Cleanse Indoor Air-Research Review, Proceedings of Sixth International Conference on Indoor Air Quality, Ventilation \& Energy Conservation in Buildings-Sustainable Built Environment, 3, 249, 2007.

13. SEVIK H., CETIN M., BELKAYALI, N., GUNEY, K. The effect of some indoor plants of the amount of $\mathrm{CO}_{2}$ in the internal environment. The result of TUBITAK 3001 project. Project number 114Y033. 2015 [In Turkish].

14. SEVIK H., CETIN M., ISINKARALAR K. Effects of some indoor ornamental plants on the amount of indoor Carbondioxide. Duzce University. The Journal of Science and Technology. In press. 2015 [In Turkish].

15. TURK M., CELIK N. Determination of $\mathrm{CO}_{2}$ assimilation in $\mathrm{C}-3$ and $\mathrm{C}-4$ type of photosynthesis in plants respiratory equilibrium. Suleyman Demirel University, Journal of Science Institute, 10 (1), 48, 2006.

16. ATAYETER Y. An assessment of the air pollution in the city of Burdur, I. Burdur Symposium. 635, 16-19 November, Burdur, Turkey, 2007. 
17. ONDER S., AKBULUT C.D. Evaluation of urban green areas, open-used plant materials; an example of the city of Aksaray. Journal of Selcuk Agriculture and Food Science, 25 (2), 93, 2011.

18. YILMAZ S., BULUT Z., YESIL P. The benefits of the urban forest in the urban space. Ataturk University, Journal of Faculty of Agriculture. 37 (1), 131, 2006.
19. SEVIK H., KANTER I. The effect of indoor plants on indoor air quality. X. International HVAC Technology Symposium, Proceedings, 517, 30 April-02 May, 2012, Istanbul, Turkey, 2012. 